\title{
The Forgotten Patient: A Health Provider's GuIDE TO PROVIDING COMPREHENSIVE CARE FOR TRANSGENDER PATIENTS
}

\author{
Nikki Burrill ${ }^{*}$ \& Valita Fredland**
}

"[T]imes can blind us to certain truths and later generations can see that laws once thought necessary and proper in fact serve only to oppress. As the Constitution endures, persons in every generation can invoke its principles in their own search for greater freedom."

-Lawrence v. Texas ${ }^{1}$

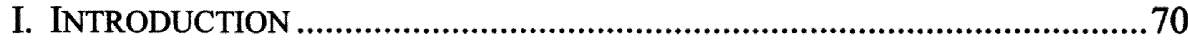

A. Is Transgender a Mental Health Disorder?..............................71

B. Sex, Gender, and Sexual Orientation........................................72

C. Patients with Intersex Condition …….......................................... 72

D. Underrepresented Populations of the Transgender

Community ……..........................................................................74

1. Elderly Transgender .......................................................... 74

2. Transgender Veterans.........................................................75

3. Incarcerated Transgender Individuals..................................76

II. THE PATIENTS' RightS IN HEALTHCARE .............................................76

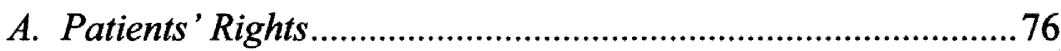

B. Transgender Patients in Health Care .......................................78

III. AN EMERGENCY ROOM VISIT.........................................................79

IV. THE EVOLUTION OF SEX AND GENDER IN AMERICAN COURTS ............81

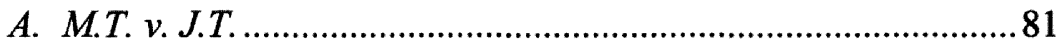

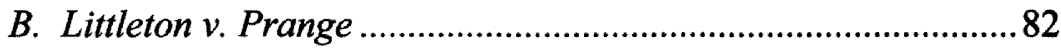

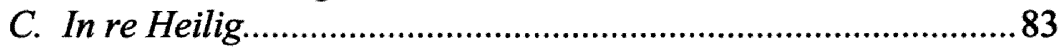

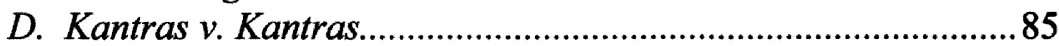

V. LEGAL IMPLICATIONS FOR TRANSGENDER HEALTH CARE RIGHTS .......86

A. The Federal Government's Failure to Protect Transgender

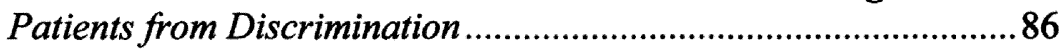

1. Americans with Disabilities Act (ADA) ..................................86

2. Title VII of the 1964 Civil Rights Act........................................ 87

a. Ulane v. Eastern Airlines.....................................................8 89

b. Schroer v. Billington............................................................. 89

* J.D. Candidate, 2012, Indiana University Robert H. McKinney School of Law; B.A., 2009, Indiana University Kelley School of Business.

** Adjunct Faculty at Indiana University Robert H. McKinney School of Law and Associate General Counsel and Chief Privacy Officer at Indiana University Health; M.S., University of Virginia, 1992; J.D., Cornell University, 1991; B.A., Mount Holyoke College, 1987.

1. Lawrence v. Texas, 539 U.S. 558,579 (2003). 
B. State Laws Affecting Transgender Patients and

Health Care

1. Amendment of Birth Certificates.........................................92

2. Amendment of Medical Records .........................................93

3. Health Care Consent and Advance Directives.....................95

VI. RECOMMENDATIONS FOR FUTURE TRANSGENDER LEGAL ISSUES ........96

VII. RECOMMENDATIONS FOR HEALTH CARE PROVIDERS .........................97

A. Adapt your Intake Forms and Intake Process...........................99

B. A Healthcare Provider's Actions and Words..........................100

1. Use of Proper Pronouns ....................................................100

2. A Provider's Approach Before Conducting an Interview... 101

3. The Interview Process.......................................................... 101

C. Be Knowledgeable on the Health Needs of Transgender

Patients.

D. Be Knowledgeable about Non-Medical Concerns of

Transgender Patients

E. Attend Trainings/Seminars Dedicated to the Needs of

Transgender Patients

F. Gain Experience Working with Transgender Patients.

VIII. CONCLUSION 106

\section{INTRODUCTION}

The purpose of this article is to provide information regarding the legal context of health concerns for the transgender community and to help healthcare providers create a welcoming environment for their current and future transgender patients. Furthermore, this article discusses guaranteed rights to all patients involving their medical treatment and the failures of these guarantees to transgender patients. Part II discusses patients' rights in health care and the deprivation of these rights for numerous transgender patients when being treated in a health care environment. Part III of this article will review the application of laws involved in common experiences by transgender patients in healthcare and evaluate legal issues that arise out of these experiences. Some of these legal issues include amending birth certificates to represent identified gender of patients, marriage status of transgender people and surrogate status of a partner in transgender relationships. Part IV reviews case law particular to the evolution of the definition and interpretation of the terms "sex" and "gender" in the American court system. Part V reviews statutes, both federal and state, that are relevant to transgender patients. Finally, part VI provides recommendations for healthcare providers to provide the same standard of health care to all patients, including transgender patients, within the context of laws that do not yet offer equitable rights 


\section{A. Is Transgender a Mental Health Disorder?}

“'Transgender' is an umbrella term that includes anyone whose gender identity and/or gender expression does not match society's expectations of how an individual who was assigned a particular sex at birth should behave in relation to their gender." "The following are included under the transgender umbrella: pre-operative, post-operative, and non-operative transsexuals who may or may not use hormones; intersex individuals; persons exhibiting gender characteristics and identities that are perceived to be inconsistent with their gender at birth, or gender non-conforming; persons perceived to be androgynous; transvestites; cross-dressers; or drag queens or kings. ${ }^{3}$ Male-to-female (MTF) is a common term used for those born biologically a male and chooses to identify and express themselves as a female. Conversely, female-to-male (FTM) is a common term used for those born biologically as a female and chooses to identify and express themselves as a male. $^{4}$

There is much controversy among mental health professionals and the transgender community on whether transgender should be classified as a mental health disorder. ${ }^{5}$ According to the American Psychology Association, "[a] psychological state is considered a mental disorder only if it causes significant distress or disability." Many transgender people do not feel their gender is distressing or disabling, implying it would not constitute a disorder. ${ }^{7}$ Significant obstacles for these individuals include finding affordable resources for counseling, hormone therapy, medical procedures, and finding the social support to feel comfortable expressing their gender preferences, discrimination, lack of acceptance within society, and assault. ${ }^{8}$

For payment of a claim, insurance companies such as Medicare and Medicaid require that a specific disorder be defined or specified by the International Classification of Diseases (ICD) or the Diagnostic and Statistical Manual of Mental Disorders (DSM-IV). ${ }^{9}$ Gender Identity Disorder (GID), also known as "transsexualism," is a medical diagnosis recog-

2. N.Y. COMP. CODES R \& REGS. tit. 8, § $101-131$ (2006).

3. Transgender Terminology, NAT'L Ass'N OF TRANSGENDER EQUALITY, http:// transequality.org/Resources/NCTE_TransTerminology.pdf (last visited Mar. 28, 2012).

4. Samuel Lurie, Identifying Training Needs of Health-Care Providers Related to Treatment and Care of Transgendered Patients: A Qualitative Needs Assessment Conducted in New England, in Transgender Health and HIV Prevention: NeEDS AsSessment Studies from Transgender Communities ACross the United States 93, 95 (Walter Bockting \& Eric Avery eds., 2006).

5. Answers to your Questions About Transgender People, Gender Identity, and Gender Expression, AM. PSYCHOLOGY Ass'N, http://www.apa.org/topics/sexuality/transgender. aspx (last visited Mar. 18, 2012).
6. Id.
7. Id.
8. Id.
9. Id. 
nized by DSM-IV, which is the American Psychiatric Association's encyclopedia of official diagnoses. Not every transgender person experiences GID or considers a medical transition. ${ }^{10}$ The standard clinically recommended treatment for GID involves some combination of hormone therapy, sex reassignment surgery and real-life experience living in accordance with the patient's gender identity. ${ }^{11}$

\section{B. Sex, Gender, and Sexual Orientation}

The definitions of sex, gender, and sexual orientation are becoming more commonly understood as distinct. ${ }^{12}$ Sex generally refers to individuals' biological sex, determined by "genetic material encoded in chromosomes," which typically corresponds with external genitalia and phenotype. $^{13}$ In contrast, gender typically denotes social constructions understood as male or female or masculine or feminine. ${ }^{14}$ Sexual orientation is distinct from both sex and gender, and although no one definition can be offered, it is generally understood as "the apparent or actual inclination(s) of sexual or affectional interests or desires among humans toward members of the same sex, the other sex, or both sexes," tional disposition to the same and/or opposite sex."16 Although there are literally hundreds of other definitions of sexual orientation in the literature, most of them are distinguished from sex and gender and include some sort of affectional component, not limited to sexual conduct. ${ }^{17}$ Therefore, not all transgender individuals identify their sexual orientation as gay, lesbian, or bisexual. $^{18}$

\section{Patients with Intersex Condition}

It is a common assumption to mistakenly believe that a person born

10. Transgender Rights Toolkit: A Legal Guide for Trans People and Their Advocates, Transition-Related Health Care, LAMBDA LEGAL 2, http://www.lambdalegal.org/ sites/default/files/publications/downloads/trt_transition-related-health-care_1.pdf (last visited Mar. 18, 2012).

11. Id.

12. Shawn M. Filippi \& Edward J. Reeve, Equality or Further Discrimination? Sexual Orientation Nondiscrimination in Oregon Statutory Employment Law after law after Tanner v. OHSU, 3 J. SMALl \& EMERGING BUS. L. 269, 311, (1999).

13. John C. Gonsiorek \& James D. Weinrich, The Definition and Scope of Sexual Orientation, in HomoseXuality: ResearCh IMPLICATIONS FOR PUBliC POLICY 1 (John C. Gonsiorek \& James D. Weinrich eds., 1991).

14. Francisco Valdes, Queers, Sissies, Dykes, and Tomboys: Deconstructing the Conflation of "Sex," "Gender," and "Sexual Orientation" in Euro-American Law and Society, 83 CAL. L. REV. 1, 21 (1995).

15. Id. at 23.

16. Gonsiorek \& Weinrich, supra note 13 , at 1.

17. Valdes, supra note 14 , at $22-23$

18. AM. PSYCHOLOGY Ass'N, supra note 5. 
interesexed is the same as a transgender individual. This assumption, along with the incorrect assumption that a transgender person is also homosexual, is simply not true. "People who identify as transgender or transsexuals are usually people who are born with typical male or female anatomies but feel as though they've been born into the "wrong body.",19 Contrastingly, "[p]eople who have intersex conditions have anatomy that is not considered typically male or female." 20 Both populations do commonly have similar medical treatments such as hormone therapy or sexual reassignment surgery. $^{21}$ The medical needs of interesexed individuals and the failure to fit into the binary construct of gender, creates legal gaps for interesexed individuals that are similar to those of transgender individuals.

There are conflicting theories on how to clinically treat intersex babies. A majority of physicians in the United States believe that the standard practice is to "normalize" the external genitalia of an intersex baby to conform to societal expectations of gender, also called the "ConcealmentCentered Model."22 The Concealment-Centered Model allows doctors to decide based on medical tests what gender identity they believe the child will find most comfortable. ${ }^{23}$ Doctors determine whether the child has a Y chromosome and an adequate or "reconstructable" penis, if so, the child will be assigned a male gender. ${ }^{24}$ For newborns, the baby must have a penis of 1 inch or larger to be assigned the male gender. ${ }^{25}$ If the child has a Y chromosome and an inadequate or "unreconstructable" penis according to doctors, the child will be assigned a female gender and surgically "reconstructed" as such. ${ }^{26}$ If the child has no $\mathrm{Y}$ chromosome, it will be assigned the female gender. ${ }^{27}$ The genitals will be surgically altered to look more like what doctors think female genitals should look like, this may include clitoral reduction surgeries and construction of a "vagina."28

Certain intersex activists have been promoting a competing treatment theory that states that a majority of procedures performed on intersex babies are for societal purposes and not for medical concerns. ${ }^{29}$ This theory is called the, "Patient-Centered Model."30 The Patient Centered Model sug-

19. What's the difference between being transgender or transsexual and having an intersex condition?, INTERSEX SOC'Y OF N. AM., http://www.isna.org/faq/transgender (last visited Mar. 18, 2012).

20. Id.

21. Id.

22. Id.

23. Shifting the Paradigm of Intersex Treatment, INTERSEX SOC'Y OF N. AM., http://www.isna.org/compare (last visited Jan. 16, 2012).

24. Id.

25. Id.

26. Id.

27. Id.

28. Id.

29. Id.

30. Id. 
gests individuals with intersex condition have a right to self-determination of their own bodies and should not be forced to undergo irreversible surgeries or treatments. ${ }^{31}$ The activists argue that "[d]ecisions regarding more permanent medical creation of sex attributes, including genital surgery, should be delayed until the child is old enough to participate in the decision along with family and medical professionals." ${ }^{32}$ Like intersex individuals, the health care needs of smaller populations within the transgender community can fall between the cracks when discussing the overall health care needs of transgender patients.

\section{Underrepresented Populations of the Transgender Community}

Like any population, the transgender community has segments that have been victims of additional discrimination. Three sectors of the transgender community typically not considered are 1) the elderly transgender, 2) transgender veterans, and 3) the incarcerated transgender. All three of these populations are particularly vulnerable either due to age, capability, limited health care coverage, or limits on freedom. Both health care professionals and legal professionals should be cognizant of these underrepresented populations in the transgender community and be responsive to their specific health care needs.

\section{Elderly Transgender}

The needs of the elderly transgender are similar to those of the elderly non-transgender. These needs arise from the loss or death of a spouse or partner, decreased ability to maintain a private residence, loss of driving ability, transition from independent residence to an assisted living facility, and the loss of personal control. ${ }^{33}$ In the case of elderly transgender individuals, these challenges are compounded by issues regarding disclosure, privacy, isolation from transgender peers, specialized health care needs, and the potential for judgment and discrimination from health care professionals. ${ }^{34}$ Medically, transgender elders face not only the normative problems of aging, but also, due to their hormone use and other procedures, increased health care needs. ${ }^{35}$ Elderly that transitioned earlier in life have health concerns relating to long term stress from living a significant amount of their

31. Id.

32. Jennifer Rellis, Please Write ' $E$ ' In the Box" Toward Self-Idenfitication and Recognition of a Third Gender: Approaches in the United States and India, 14 MicH. J. GENDER \& L. 223, 224 (2008).

33. See generally Tarynn Witten \& Stephen Wittle, TransPanthers: The Graying of Transgender and the Law, 9 DEAKIN L. REV. 504 (2006), available at http://www.deakin. edu.au/buslaw/law/dlr/docs/vol9-iss2/vol9-2-10.pdf.

34. Id.

35. Id. at 3 . 
adult life as their identified gender. ${ }^{36}$ All of the issues faced by transgender elderly are further exacerbated when they are also a member of other minorities such as race, ethnicity, immigrant, disability and/or having HIV/AIDS. ${ }^{37}$

"While living in nursing homes can be stressful for any elderly person, aging gay, lesbian, bisexual, and transgender (LGBT) Americans are especially susceptible to abuse, neglect, and discrimination caused by homophobia."38 "LGBT elders are more vulnerable because they are members of a minority group that is often subjected to emotional and physical hostility and they are often the first targets of abuse, neglect, and discrimination in nursing homes. ${ }^{39}$ Although case law concerning the discrimination against LGBT individuals in assisted care facilities is scarce, like many other assisted care residents, these residents are still subjected to prevalent neglect and abuse. ${ }^{40}$ In a recent survey, LGBT respondents to a survey reported the greatest homophobia in nursing homes came from the staff, followed closely by administration and other residents. ${ }^{41}$ For a majority of the population, an elderly LGBT individual does not come to mind when speaking of the LGBT population. ${ }^{42}$ Therefore, this population of elderly individuals is not visible to the American population and is easily hidden, making them target of abuse and neglect. ${ }^{43}$

\section{Transgender Veterans}

Unfortunately, the legal road for transgender veterans includes a turbulent history. Currently, the Veterans' Affairs Health System does not cover gender reassignment surgery or "gender alterations for veterans." a 2008 survey, a California research center found that transgender veterans felt they were disrespected and discriminated against while at Veterans' Affairs medical facilities. ${ }^{45}$ Similar to stories from transgender patients at other medical facilities, transgender veterans were insulted when medical staff would not use the gender-appropriate pronouns while referring to the

36. Id. at 34 .

37. Id. at 7 .

38. Jaime E. Hovey, Note: Nursing Wounds: Why LGBT Elders Need Protection from Discrimination and Abuse Based on Sexual Orientation and Gender Identity, 17 ELDER L.J. 95, 95 (2009).

39. Id.

40. Id. at 96

41. Id. at 112 .

42. Id. at 100 .

43. Id.

44. Departments of Veterans Affairs, Medical Benefits Package, 38 C.F.R. $\S 17.38$ (2011)

45. Rick Maze, Study: Transgender Vets Face Discrimination, AIR FoRCE TIMES, Aug. 25, 2008, available at $\mathrm{http}: / / \mathrm{www}$.airforcetimes.com/news $/ 2008 / 08 / \mathrm{military}$ transgender_veterans_082508w/. 
transgender veteran. ${ }^{46}$ "Transgender veterans also complained that their privacy has been violated by medical staff, including one incident in which a nurse pulled a veterans' partner into the hall to ask if the partner knew that the veteran was born a man."47

\section{Incarcerated Transgender Individuals}

In addition to facing difficulties relating to health needs, transgender inmates are commonly targets of sexual, physical, and emotional assault. ${ }^{48}$ Transgender inmates are routinely assigned housing not in accordance with the gender in which they identify. ${ }^{49}$. Occasionally, correctional facilities find it appropriate to leave the transgender inmate in an isolation cell or block, leaving the inmate at a greater risk of sexual assault or rape. "The U.S. Supreme Court has held that every inmate, regardless of gender identity, is entitled to reasonable medical care."51 52 Unfortunately, due to tight budgets and the cost of travel for specialized surgeons, transgender inmates' health care needs are met with high resistance from correctional facility administrations in the United States. Currently, Great Britain and Canada provide gender reassignment surgery to their prisoners. ${ }^{53}$ Refer to Exhibit A for nine recommended principles for correctional health professionals to follow in providing for the needs of transgender prisoners made available by The National Commission on Correctional Health Care. ${ }^{54}$

\section{THE PATIENTS' RIGHTS IN HEALTHCARE}

\section{A. Patients' Rights}

A patients' bill of rights is a document that lists specific promises by an organization to patients when they receive medical care. In 1973, the American Hospital Association developed a patient bill of rights to inform patients of what they could reasonably expect while hospitalized and offer a way for hospitals to talk with patients about their care. ${ }^{55}$ In 2003 , an updat-

46. Id.

47. Id.

48. Transgender Health Care in Correctional Settings, NAT'L COMM'N OF CORR. CARE, http://www.ncchc.org/resources/statements/transgender.html.

49. Ally Windsor Howell, $A$ Comparison of the Treatment of Transgender Persons in the Criminal Justice Systems of Ontario, Canada, New York and California, 28 Buff. PUB. INT. L. J. 133, 145 (2010).

50. Id.

51. Farmer v. Brennan, 511 U.S. 825, 832 (1994).

52. Howell, supra note 49 , at 152.

53. Howell, supra note 49, at 177-179.

54. NAT'L COMM'N OF CORR. CARE, supra note 48.

55. Patient's Bill or Rights, AM. CANCER SOC'Y, http://www.cancer.org/Treatment/ FindingandPayingforTreatment/UnderstandingFinancialandLegalMatters/patients-bill-of- 
ed version was published by the AHA called, "The Patient Care Partnership." Both the 2003 and 1973 documents by the AHA are not legally binding documents but were meant to be used as a guide for health care providers, patients, and organizations. ${ }^{56}$ Some of the general patients' rights listed by the AHA and other patients' bill of rights modeled after the AHA include, high quality hospital care, a clean and safe environment, patient's involvement in care, protection of privacy, help with a patient's bill and filing of insurance claims, and preparing the patient and the patient's family for when the patient leaves the hospital. ${ }^{57}$ More recently updated patients' bill of rights typically include a right for patients to be treated with respect and non-discrimination, meaning patients have a right to be given respectful care from their doctors and other health care providers and to not be discriminated against based on race, ethnicity, national origin, religion, sex, age, mental or physical disability, sexual orientation, genetic information, or source of payment. ${ }^{5859}$

After reading a patient's right to non-discrimination, it would be reasonable to deduce that transgender patients would be free from discrimination based on either their sex or possibly their sexual orientation. This assumption would not be accurate. According to a 2010 survey of about 7,000 people by the National Center for Transgender Equality and the National Gay and Lesbian Task Force called Injustice at Every Turn, twentyeight percent of transgender or gender nonconforming people postponed medical care when they were sick or injured due to concerns about discrimination and forty-eight percent of respondent postponed care because of inability to afford care. ${ }^{60}$ Additionally, twenty-eight percent of respondents reported being victims of verbal harassment in a medical setting, and two percent were victims of physical violence in a doctor's office. ${ }^{61}$ "Many transgender people face a tremendous number of barriers when trying to access the healthcare system for day-to-day issues like a sore throat or a scrape of the knee, issues that somebody ordinarily can go to their doctor for without fear of discrimination or humiliation." The same survey found that nineteen percent of the participants reported being refused medical care due to their transgender or gender non-conforming status. ${ }^{63}$ It is important

rights (last updated Dec. 22, 2011).

56. Patient Care Partnership, AM. Hosp.. Ass'N, http://www.aha.org/advocacyissues/communicatingpts/pt-care-partnership.shtml (last visited Jan. 16, 2012).

57. Id.

58. AM. CANCER SOC'Y, supra note 55.

59. Patient Rights \& Responsibilities, INDIANA UnIV. HEALTH, http://iuhealth.org/ methodist/legal-notices/patient-rights-responsibilities/ (last visited Jan. 16, 2012).

60. Jaime M. Grant et al., INJUSTICE AT EVERY TURN: A REPORT OF THE NATIONAL TRANSGENDER DISCRIMINATION SURVEY 6 (2011), http://www.thetaskforce.org/downloads/ reports/reports/ntds_full.pdf.

61. Id.

62. Michael Silverman, Issues in Access to Healthcare by Transgender Individuals, 30 WOMEN'S RTS. L. REP. 347, 348 (2009).

63. Grant et al., supra note 60 . 
to recognize that discrimination towards transgender people occurs in healthcare facilities, regardless of non-discrimination policies. ${ }^{64}$ "It is not necessarily intentional discrimination, but rather the result of a system that has never stopped to ask how we can address the needs of this population.

\section{B. Transgender Patients in Health Care}

According to Transgender Legal Defense and Education Fund, a nonprofit organized to end discrimination based upon gender identity ${ }^{66}$ many of its transgender clients face real, active hostility in the healthcare system based upon their gender identity. Thus, it is not surprising that transgender people feel hesitant to seek help from medical professionals. In addition, a medical professional may diagnose the transgender patient's condition instead of approaching the transgender patient's individual medical needs. ${ }^{67}$ For example, in the survey conducted in Injustice at Every Turn, one respondent stated, "I was forced to have a pelvic exam by a doctor when I went in for a sore throat. The doctor invited others to look at me while he examined me and talked to them about my genitals." ${ }^{68}$ It is not uncommon that transgender patients 'are treated as 'specimens' and become the butt of jokes." ${ }^{, 69}$ Whether intentional or not, healthcare professionals and other patients can find themselves guilty of offending a transgender patient with inadvertent actions such as leering. Furthermore, a healthcare provider may inadvertently offend a transgender patient if the provider is hesitant when answering a patient's question.

It is important for providers to be educated on the health needs of transgender patients and the legal context of healthcare for transgender patients. Furthermore, providers, along with legal professionals, need to understand legal issues that can occur in a transgender patient's life outside of the healthcare environment, as these legal issues may have an impact on the health care provider's ability to provide care or the quality of care for the transgender patient. Through cooperation, legal and healthcare professionals can help the transgender community achieve total healthcare inclusion. ${ }^{70}$

64. Id.

65. Silverman, supra note 62.

66. TLDEF: About TLDEF, Transgender Legal Def. \& Educ. Fund, http://www.transgenderlegal.org/page.php?id=2 (last visited Jan. 16, 2012).

67. Anne C. DeCleene, The Reality of Gender Ambiguity: A Road Toward Transgender Health Care Inclusion, 16 L. \& SEX. 123, 135 (2007).

68. Grant et al., supra note 60.

69. Id.

70. Id. at 125 . 


\section{AN EMERGENCY ROOM VISIT}

Michelle and Leonard have been married for approximately five years. Leonard had a previous marriage of twenty-five years that ended in divorce. $^{71}$ From that previous marriage, Leonard has two adult children. Three years after his divorce, Leonard met Michelle at a fundraiser for a mutual friend. Leonard found in Michelle a soul mate and best friend. While they were dating, Michelle felt it was necessary to explain to Leonard her prior history of having been born biologically a male. Michelle explained that throughout her childhood she had felt something was "wrong" even during pre-puberty. She felt as if she was a girl with a "birth defect" of penis and testicles. Leonard was not concerned about Michelle's past and felt they were meant to be together. Leonard married Michelle six months later.

Michelle worked as the store manager at a local flower shop. During a Valentine's Day rush at the flower shop, a man came to the store and opened fire on the employees and patrons. Michelle was among two people shot during the incident, and was rushed to the local emergency room. As her husband and emergency contact, Leonard was notified of the accident and met Michelle at the hospital. The hospital staff met with Leonard, who had identified himself as Michelle's husband, to speak with him about emergency surgery to remove the bullet. Michelle had been treated with pain medications, leading the surgical staff to feel that she was not capable to consent to any care. (Note: The law for surrogate health care consent will be further explained later in this article.) Leonard felt it was in Michelle's best interest to have the surgery and gave his consent to the surgical staff. The surgical staff began the procedure immediately. Upon successful completion of the procedure, the surgical staff discovered Michelle was biologically born a male. The surgical staff was concerned that they were not notified of the patient's history prior to the procedure and became worried about Leonard's legal standing to consent to Michelle's surgery because the law does not recognize same-sex partner as a legal spouse and thus consequently neither a legal surrogate.

Meet Joanne, a forty-two year old transgender woman, who was biologically born as a male. ${ }^{72}$ Joanne has three young adult children and a wife named Cindy with whom she had been married for fifteen years. Joanne was biologically born a male and given the name Jon. During childhood, Jon was never comfortable with his body. Jon always felt he was born the incorrect sex and would occasionally dress in women's clothing in private. Jon never told anyone about his feelings because he was scared of his fami-

71. The following story was loosely based the facts of In re Estate of Gardiner, 273 Kan. 191, 194 (2002) and other research.

72. The following story was inspired by Our America with Lisa Ling: Transgender Lives (Oprah Winfrey Network television broadcast Feb. 22, 2011). 
ly and the community's reaction. Furthermore, Jon was confused about his feelings because while he felt he was a woman, he was attracted to females. Jon felt it was best to ignore his feelings concerning his gender and attempt to grow-up like "any normal kid." In college, Jon met his wife Cindy during his freshman year in their psychiatry class. Jon and Cindy got married the summer after their college graduation and had their first baby two years later.

After raising three beautiful children, Jon felt he could no longer ignore his feelings and it was finally time to have a conversation with Cindy. When sitting down with Cindy, Jon was terrified, like many transgender individuals are, when giving this news to a spouse, that Cindy would leave him. Jon was risking the loss of his wife, children, extended family, and even his job. However, Jon felt he had lived over half of his life in discomfort and in a lie. As Jon had feared, Cindy was upset and distraught by the news that her husband had given her. Jon told Cindy that he was transgender and finally felt it was time for him to start living his life as a woman.

After some time and consideration, Cindy felt Jon was her best friend of over fifteen years. She could not imagine her life without him. She had taken a promise to love and support him through all of their struggles. Cindy and Jon decided to have a family meeting with their three children and explain to them that their father was transgender. Like Cindy, the children needed some time to process the new information. Ultimately, the children were extremely supportive of their father. Jon changed his name to Joanne and, with the help of his wife and children, began living publicly as a woman.

After only two years of living publicly as a woman, Joanne was in a dreadful car accident that caused her to visit the local emergency room. Upon admittance to the emergency room, Joanne was a victim of inappropriate whispers and leers by the hospital staff. Although Joanne was scared and in extreme pain, providers forced her to explain her physical appearance by asking her uncomfortable questions during her exam. Such unjust practices, although possibly without the intent to discriminate, can have devastating effects on transgender patients' comfort in going to healthcare facilities. Strategies on how to avoid this problem in a healthcare facility will be addressed later in the recommendations section [insert section number].

Another problem occurred upon Cindy's arrival to the hospital. When Cindy arrived in the emergency room and claims to be the wife of the transgender woman patient, do you question the validity of her marriage? What if Joanne was unable to give consent to any life saving procedure that is needed, do you accept Cindy's consent in substitution for Joanne's consent? Like the earlier example of a transgender male with a biological female, Joanne and Cindy's situation raises many concerning questions about the marital and surrogate rights of transgender spouses. Regrettably, the 
answers to these questions are still unclear under the law.

\section{THE EVOLUTION OF SEX AND GENDER IN AMERICAN COURTS}

$$
\text { A. M.T. v. J.T. }
$$

The first meaningful precedent specifically referring to a transgender individual was in 1976 in the Superior Court of New Jersey in M.T. v. J.T. ${ }^{73}$ The Plaintiff, M.T., was biologically born a male. ${ }^{74}$ The plaintiff met the defendant and told him about his feelings of identifying as a woman her entire life. ${ }^{75}$ After living together as a couple, the plaintiff consulted a physician about options for sexual reassignment surgery. ${ }^{76}$ The plaintiff eventually did undergo sexual reassignment surgery that was funded by the defendant. $^{77}$ Additionally, M.T. amended her birth certificate to demonstrate her identified gender. ${ }^{78}$ Subsequently, two years after the plaintiff's operation, the defendant decided to leave the plaintiff. ${ }^{79}$ The plaintiff filed suit for spousal support. ${ }^{80}$

The court began its analysis by giving an overview of an English case Corbett $v$. Corbett. ${ }^{81}$ The Corbett court found that a transsexual's gender was defined by their biological sex of the person at birth. ${ }^{82}$ The M.T. court respectfully disagreed with Corbett, finding there are "several criteria or standards which may be relevant in determining the sex of an individual.,"83 The M.T. court stated that:

Our departure from the Corbett thesis is not a matter of semantics. It stems from a fundamentally different understanding of what is meant by "sex" for marital purposes. The English court apparently felt that sex and gender were disparate phenomena. ... The evidence and authority which we have examined, however, show that a person's sex or sexuality embraces an individual's gender, that is, one's self-image, the deep psychological or emotional sense of sexual iden-

73. M.T. v. J.T., 355 A.2d 204, 205 (N.J. Super. Ct. App. Div. 1976).

74. Id.

75. Id.

76. Id.

77. Id.

78. Id. at 205.

79. Id.

80. Id.

81. Id. at 208 (citing Corbett v. Corbett, (1970) 2 All E.R. 33 (U.K.)).

82. Id. (citing Corbett v. Corbett, (1970) 2 All E.R. 33 (U.K.)).

83. $I d$. 
tity and character. ${ }^{84}$

In a 1966 case brought by a transgender female seeking to obtain a court order to have her birth certificate changed to reflect her new gender, the court reasoned that it was in the public's interest to not allow a transsexual to change her gender on her birth certificate because it protected against fraud. ${ }^{85}$ The M.T. court agreed with the following statement made by the dissenting trial court judge in Weiner, who stated, "[ $t]$ he transsexual is not committing a fraud upon the public. In actuality she is doing her utmost to remove any false façade. ${ }^{, 86}$ The M.T. court held that if sexual reassignment surgery is successful and a transsexual's psychological gender and genitalia are in harmony, the court did not perceive any legal barrier or ground in public policy to prevent that individual from entering into a marriage. ${ }^{87}$ The court in M.T. found that the plaintiff was a female at the time of the marriage and the defendant was obligated to pay spousal support to the plaintiff. $^{88}$

\section{B. Littleton v. Prange}

In 1995, a Texas Court of Appeals disagreed with M.T v. J.T. when it heard Littleton $v$. Prange. ${ }^{89}$ In that case, a transsexual female named Christie was born with male genitalia. ${ }^{90}$ Christie testified that she felt she was a female since she was three to four years old. ${ }^{91}$ At the age of nineteen and over the next for four years, Christie took steps to transition genders including the use of hormones, and psychological and psychiatric treatment by a physician. ${ }^{92}$ Finally, Christie underwent sexual reassignment surgery at the age of twenty-three years old. ${ }^{33}$ Christie's treatment was conducted by a multi-disciplinary team of physicians that met regularly to interview and care for transsexual patients. ${ }^{94}$ Two of those physicians testified at trial that Christie was medically a woman. ${ }^{95}$

Christie met a man named Mark Littleton, with whom she lived until the time of his death in $1996 .^{96}$ Upon Littleton's death, Christie filed a wrongful death claim against Littleton's treating physician, as Littleton's

84. Id. at 209.

85. Anonymous v. Weiner, 270 N.Y.S.2d 319 (N.Y. Sup. Ct. 1966).

86. Id. at 210 .

87. Id. at $210-211$.

88. Id. at 211 .

89. Littleton v. Prange, 9 S.W.3d 223 (Tex. 1999).

90. Id. at 224 .

91. Id.

92. Id.

93. Id.

94. Id.

95. Id.

96. Id. at 225 . 
surviving spouse. ${ }^{97}$ The defendant filed a motion for summary judgment, claiming that Christie, as a biologically born male, could not be the surviving spouse of Littleton because same-sex marriage was not legal in Texas. ${ }^{98}$ In its analysis the court also referred to biological analysis used in the English case Corbett $v$. Corbett. ${ }^{99}$ Using the Corbett analysis, the Littleton court found that chromosomes were not changed by use of either hormonal treatments or sexual reassignment surgery. ${ }^{100}$ This allowed the court to hold that Christie, a post-operative female transsexual, was still biologically a male, and since a male cannot be married to another male under Texas law, Christie's marriage to Jonathon Littleton was invalid. Consequently, she did not have standing to bring a wrongful death suit as a surviving spouse. $^{101}$

Interestingly, the dissenting opinion in Littleton relied on the rules of civil procedure and the burden of proof on the defendant ${ }^{102}$ to conclude that by permitting Christie's birth certificate to lawfully be amended to show a corrected name and gender, Texas had allowed for gender inaccuracies to be corrected. ${ }^{103}$ The amended birth certificate reflected the original filing date, the original issuance date, and the amended issuance date. ${ }^{104}$ "Under the rules of civil procedure, a document that has been replaced by an amended document is considered a nullity." "[Tex "[Tas Rules of Civil Procedure] Rule 65 provides that the substituted instrument takes the place of the original."106 As a result, the dissent claimed the majority based its decision on a nullified document that should not have been considered and that summary judgment should not have been granted. ${ }^{107}$

\section{In re Heilig}

In 2003, a Maryland appellate court concluded in In re Heilig that gender can be subject to modification or adjustment. ${ }^{108}$ The petitioner, Robert Heilig, was born as a biological male in Pennsylvania ${ }^{109}$ and sought an order to change his name and gender in a Maryland court to female. ${ }^{110}$ Attached to her petition were supporting letters from two health care pro-

97. Id.

98. Id.

99. Id. at 227 (citing Corbett v. Corbett, (1970) 2 All E.R. 33 (U.K.)).

100. Id. at 230 .

101. Id. at 231 .

102. Id. at 233.

103. Id.

104. Id.

105. Id.

106. Id.

107. Id.

108. DeCleene, supra note 67, at 133.

109. In re Heilig, 816 A.2d 68, 69 (Md. 2003).

110. Id. 
fessionals, an endocrinologist, overseeing Heilig's hormone therapy, and a licensed social worker, involved in Heilig's psychotherapeutic treatment as a transsexual woman. ${ }^{111}$ The Circuit Court of Montgomery entered an order to change Heilig's name on her birth certificate but refused to correct her gender on the document, stating that "gender had physical manifestation and was not subject to change." 112 The Court of Special Appeals affirmed the decision of the lower court. ${ }^{113}$ Upon appeal, the Court of Appeals of Maryland found that despite the supporting clinical letters presented by Heilig, there was no medical evidence presented to the court regarding Heilig's gender. ${ }^{114}$ More importantly, the court concluded that the lower court "erred in broadly concluding, apparently as a matter of law, that gender was not subject to modification or adjustment." 115

When conducting its own research, the court stated, "[i]n the context before us, the terms 'sex' and 'gender' are not necessarily synonymous for all purposes, and indeed, the perceived distinction between them, to some extent, lies at the core of transsexualism." "The term 'sex' is often used to denote anatomical or biological sex, whereas 'gender' refers to a person's psychosexual individuality or identity."117 Additionally, the Heilig court recognized that the medical profession generally acknowledges certain clinical factors to determine a person's gender. ${ }^{118}$ The factors are as follows: 1) internal morphological sex, 2) external morphological sex, 3) gonadal sex, 4) chromosomal sex, 5) hormonal sex, 6) phenotypical sex, and 7) personal sexual identity. ${ }^{1.9}$ The court cautioned that not all seven factors are relevant in all cases. ${ }^{120}$ The Heilig court took the liberty to conduct thorough research on the subject matter of the case before them. After considering the application of the clinical gender factors, the court went even further, giving an overview of related issues such as sexual ambiguity at birth, intersex individuals, recent studies on transsexualism being related to conditions in the womb, current medical opinion on genitalia, recognition of transsexuals' right to marry in other countries, and birth certificate amendments in other jurisdictions. ${ }^{121}$ Ultimately, the court remanded the case to the trial court to reconsider in light of the notable research by the court. $^{122}$

114. Id. at 87 .

115. Id.

116. Id. at 72 .

117. Id.

118. Id. at 73 .

119. Id.

120. Id.

121. Id. at 73-79.

122. Id. at 87 . 


\section{Kantras v. Kantras}

In Kantras v. Kantras, a Florida Court of Appeals in 2004 followed what is called the "common meaning of male and female . . . to refer to immutable traits determined at birth."123 Margo Kantras was born as a biological female. ${ }^{124}$ Margo changed her name to Michael and underwent sexual reassignment surgery. Michael met Linda, who was pregnant at the time by her previous boyfriend. ${ }^{125}$ Linda was aware of Michael's past surgeries and biological sex. ${ }^{126}$ The couple filed for a marriage license, representing Michael as a male. Michael filed for adoption of Linda's son, representing himself as Linda's husband. ${ }^{127}$ Then, Linda gave birth to a daughter using artificial insemination and the sperm of Michael's brother. ${ }^{128}$ Later, Michael filed for dissolution of marriage and custody of both children. ${ }^{129}$ Linda answered, claiming the marriage was void, Michael's adoption of her son was against Florida's ban on homosexual adoption, and Linda's daughter was not Michael's biological child. ${ }^{130}$

The trial court found that Michael had successfully completed the full process of sexual reassignment and Linda was fully aware of his sex reassignment at the time of the couple's marriage. ${ }^{131}$ The trial court further stated that chromosomes are not the only factor in determining the sex of an individual and do not override gender or self-identity, meaning the marriage of Michael and Linda was legal. ${ }^{132}$ The trial court relied heavily on the Australian family court case, In re Kevin..$^{133}$ The trial court had stated that the In re Kevin court, "correctly states the law in modern society's approach to transsexualism." The District Court of Appeal of Florida, however, agreed with Kansas, Ohio, and Texas that an individual's sex is determined at birth. ${ }^{136}$ The question of whether post-operative transsexuals are authorized to marry a member of their birth sex was a matter left to the Florida legislature. ${ }^{137}$ This holding made the marriage between Michael and Linda void. ${ }^{138}$ The court further remanded the issue of custody to be

123. Kantaras v. Kantaras, 884 So.2d 155, 161 (Fla. Dist. Ct. App. 2004).

124. Id. at 156 .

125. Id.

126. Id.

127. Id. at 157.

128. Id.

129. Id. at 156 .

130. Id.

131. Id. at 157.

132. Id.

133. In re Kevin, 28 Fam. L.R. 158 (Austl. Fam. Ct. 2003).

134. See Kantaras v. Kantaras, 884 So.2d 155, 160 (Fla. Dist. Ct. App. 2004).

135. Id. at 160 .

136. Id. at 161 .

137. Id.

138. Id. 
determined by the trial court under the determination that the marriage is void. $^{139}$

As shown, there are conflicting definitions of "sex" and "gender" among the courts. Several courts have taken the view of the Kantras court by stating it is beyond the powers of the courts to determine the rights of transgender individuals and, rather, is only within the power of the legislature. Courts can only interpret the statutes set out by the legislature. The thorough approach taken by the Heilig court to conduct research on recent social studies and medical opinions, allows for legal definitions of "sex" and "gender" to be in agreement with medically accepted definitions previously stated. If followed by future courts, the Heilig interpretation would not only unite the medical and legal professions, but it would allow for more rights to transgender patients and protections from discrimination.

\section{LEGAL IMPLICATIONS FOR TRANSGENDER HEALTH CARE RIGHTS}

Law strongly supports the traditional recognition of only "male" and "female" genders. ${ }^{140}$ Yet, as the courts struggle to define gender, it is clear it is not a straightforward matter. ${ }^{141}$ Similarly, social norms have not yet settled on a commonly accepted way to define or label these individuals as previously assumed. ${ }^{142}$ Such standards of society and the law on sex and gender have created legal implications and pitfalls for transgender individuals in a variety of settings, (e.g., employment, family law, health care, etc.) and for the friends and family of the transgender individual.

\section{A. The Federal Government's Failure to Protect Transgender Patients from Discrimination}

\section{Americans with Disabilities Act (ADA)}

The federal government does not protect transsexuals from discrimination because gender dysphoria and transsexuals are excluded from protection under the American with Disabilities Act. ${ }^{143}$ The ADA protects Americans from discrimination based on a particular medical condition by a private employer, insurers, and health care providers. ${ }^{144}$ The ADA provides individuals with a claim of action against their employer's insurance com-

139. Id.

140. DeCleene, supra note 67 , at 129.

141. Id.

142. Id.

143. Gary S. Mogel, J.D., Employment Handicap Discrimination Based on Gender Dysphoria (Transsexualism), 25 AM. JUR. 3D Proof of Facts 415 (2011).

144. Kari E. Hong, Categorical Exclusions: Exploring Legal Responses to Health Care Discrimination Against Transsexuals, 11 COLUM. J. GENDER \& L. 88, 89 (2002). 
pany to guarantee the company complies with the anti-discrimination provisions of the ADA. ${ }^{145}$ "Pragmatically speaking, the ADA definition of 'disability' is the only means by which people can receive protection from discrimination." 146 In the "definitions" section of the ADA, the following clause explicitly excludes transgender individuals from protection under the ADA:

Homosexuality and Bisexuality-for purpose of the definition of "disability" does not include homosexuality, bisexuality, transvestism, transsexualism, pedophilia, exhibitionism, voyeurism, gender identity disorders not resulting from physical impairments, or other sexual behavior disorders. ${ }^{147}$

As discussed earlier, Gender Identity Disorder (GID), also known as transsexualism, has been recognized by the American Psychiatric Association's encyclopedia of official diagnoses. This often leads to the argument made by some individuals that the ADA should be altered to define GID or transsexualism as a "disability."148 This argument is controversial in the LGBT community as transsexual activists have shown concerns that GID as a disability will be used against them to prevent the transgender community from entering mainstream society as health and therefore equal. ${ }^{149}$

\section{Title VII of the 1964 Civil Rights Act}

The provided case law involving Title VII of the 1964 Civil Rights Act and transgender plaintiffs, involve claims by transgender plaintiffs against employers for employment discrimination. Typically, the discriminatory action is alleged to have occurred when the transgender employee either decided to transition while currently employed or was discriminated against in the interviewing process. ${ }^{150}$ There have been successful cases brought by transgender employees by arguing that transgender employees are protected from discrimination under Title VII of the 1964 Civil Rights Act. $^{151}$ The relevant section of the statute states it is unlawful for an em-

145. Id.

146. Id.

147. Americans with Disabilities Act of 1990, Pub. L. No. 101-336, § 511, 1990 Stat. 933 (1990).

148. Hong, supra note 144 , at 104-107.

149. Id.

150. Equal Opportunity for Individuals with Disabilities, Definitions, 42 U.S.C. $\S$ 12211(b)(1) (2011).

151. Ilana Gelfman, Because of Intersex: Intersexuality, Title VII, and the Reality of Discrimination "Because of . . . [Perceived] Sex", 34 N.Y.U. REV. L. \& SoC. CHANGE 55, 56 (2010). 
ployer "to fail or refuse to hire or to discharge any individual, or otherwise to discriminate against any individual with respect to his compensation, terms, conditions, or privileges of employment, because of such individual's race, color, religion, sex, or national origin."152

The statute [Title VII] did not provide guidelines for proving these acts of discrimination; however, the courts, including the Supreme Court, have developed a large body of case law in the area and created requirements for proving illegal discrimination of various types in the workplace. It is the case law, rather than the statute, which sets out how a judge or jury should determine if discrimination has occurred "because of . . . sex.". 153

Recently, courts have begun to apply a more liberal interpretation of Title VII's prohibition of sex discrimination with regard to transgender plaintiffs. ${ }^{154}$

Title VII cases involving transgender plaintiffs have implications to health care because 1) health care organizations are employers and 2) transgender patients have an increased chance losing their jobs and therefore, their health insurance, which could interrupt any current treatments or therapies. First, we've been discussing transgender individuals as patients, but numerous transgender patients are also health care professionals. As transgender health care professionals, these individuals are employees; as such their employment status may be vulnerable if they decide to transition. Further, health care organizations, as employers, should be aware of the current case law and trends in interpreting. Title VII as applied to transgender employees. Second, health care professionals should be aware of the life stressors their transgender patients may endure such as losing their employment, and in turn their health care insurance, after beginning the process to transition to their self-identified gender. Health care professionals should be prepared to assist transgender patients in obtaining alternative medical insurance or other means of financial support. Lastly, the cases brought under Title VII demonstrate a recent change by federal courts of interpreting the term "sex" within sexual discrimination claims to include discrimination against transgender employees. ${ }^{155}$

152. The Public and Welfare, Unlawful Employment Practices, 42 U.S.C. $\S 2000 \mathrm{e}-$ 2(a)(1) (2012).

153. Gelfman, supra note 151, at 59-60.

154. See Schroer v. Billington, 577 F.Supp.2d 293 (D.C. 2008); Nuskey v. Hochberg, 657 F. Supp.2d 47 (D.D.C. 2009).

155. See Schroer v. Billington, 577 F.Supp.2d 293 (D.C. 2008); Nuskey v. Hochberg, 657 F. Supp. 2d 47 (D.D.C. 2009). 


\section{a. Ulane v. Eastern Airlines}

The leading precedent cited by courts in regard to the narrow interpretation of Title VII's prohibition of sex discrimination, involving a transgender plaintiff, is the 1984 case of Ulane $v$. Eastern Airlines. ${ }^{156}$ Ulane was a licensed pilot with previous experience flying combat missions in Vietnam for the United States Army. ${ }^{157}$ After retiring from the military, Ulane worked as a pilot for Eastern Airlines in $1968 .^{158}$ Ulane began identifying as a transsexual in 1979 and started a physical transition in 1980 with the use of hormones and sexual reassignment surgery. ${ }^{159}$ Ulane was discharged from her employment with Eastern Airlines in 1981. ${ }^{160}$ After being fired, Ulane filed a sexual discrimination claim on two counts, first alleging she was discriminated against as a transsexual and second, that she was discriminated against as a female. ${ }^{161}$ Reversing the trial court's decision in favor of Ulane, the Seventh Circuit found that Title VII does not protect transsexuals. ${ }^{162}$ The court stated, "a prohibition against discrimination based on an individual's sex is not synonymous with a prohibition against discrimination based on an individual's sexual identity disorder or discontent with the sex into which they were born."163

\section{b. Schroer v. Billington}

In 2008, the District Court of Columbia took a different approach by supporting the medical definition of sex and finding for the transgender plaintiff in Schroer v. Billington. ${ }^{164}$ The plaintiff, Diane Schroer, was a male-to-female transsexual. ${ }^{165}$ Schroer applied for a position with the Library of Congress that required a security clearance. ${ }^{166}$ Schroer was well qualified for the job as a graduate of the National War College, the Army Command, the General Staff College, a master's degree, and twenty-five years experience in the U.S. Army. ${ }^{167}$ While on duty, Schroer held important staff and command positions in the Armored Calvary, Airborne, Special Forces and Special Operations Units, and was in combat operations

156. Ulane v. E. Airlines, Inc., 742 F.2d 1081, 1083 (7th Cir. 1984).

157. Id.

158. Id.

159. Id.

160. Id. at 1082 .

161. Id.

162. Id. at 1084 .

163. Id. at 1085 .

164. Amanda Raflo, Evolving Protection For Transgender Employees Under Title VII's Sex Discrimination Prohibition: A New Era Where Gender Is More Than Chromosomes, 2 CHARLOTTE L. REV. 217, 240 (2010).

165. Schroer v. Billington, 577 F. Supp. 2d 293, 295 (D.D.C. 2008).

166. Id.

167. Id. 
in Haiti and Rwanda. ${ }^{168}$ Before retiring, Schroer was a Colonel assigned to the Special Operations Command with a Top Secret, Sensitive Compartmented Information security clearance since $1987 . .^{169}$

Prior to applying for the position, Schroer was diagnosed with gender identity disorder and had been actively working with a licensed clinical social worker to successfully transition. During the interview process, Schroer was given the highest score of all applicants by all eighteen interviewers. ${ }^{170}$ Schroer was unanimously recommended for the position by the selection committee. ${ }^{171}$ Schroer was offered the position, after the employer agreed to increase the salary to be comparable to Schroer's current salary. ${ }^{172}$ Schroer then accepted the job offer. ${ }^{173}$ However, before the employer had completed and submitted the paperwork, Schroer asked one of the interviewers, Charlotte Preece, to lunch. ${ }^{174}$ Schroer wanted to tell Preece of his intention to transition to a female. ${ }^{175}$

Schroer felt the employer should be notified of his transsexuality because he was at the stage in his transition in which he would be presenting himself in public as a woman by wearing women's clothing. ${ }^{176}$ Schroer went further to explain that after a year of presenting himself as woman full-time, he would be using his vacation time to undergo sexual reassignment surgery, but the surgery would not interfere with his job requirements. ${ }^{177}$ After concerns were raised by Preece, Schroer assured Preece that Schroer's security clearance would not be influenced by his transition and if Preece had any further questions she could refer to a professional provided by Schroer. ${ }^{178}$ Additionally, to mitigate any concerns by Preece about Schroer presenting himself as a woman, Schroer showed Preece three pictures of Schroer in professional women's attire. ${ }^{179}$ Unfortunately, despite Schroer's efforts, Preece felt the pictures depicted "a man dressed in women's clothing," although Preece did not say this to Schroer at the time. ${ }^{180}$ Immediately following the conversation, Preece began to lobby against hiring Schroer for the position and ultimately decided not to hire Schroer. ${ }^{181}$ Preece testified that she had some concerns about Schroer's credibility to

168. Id.

169. Id.

170. Id. at 296 .

171. Id.

172. Id.

173. Id.

174. Id.

175. Id.

176. Id.

177. Id.

178. Id.

179. Id.

180. Id.

181. Id. at 297. 
testify in front of congress and ability to maintain his security clearance. ${ }^{182}$

The court analyzed Schroer's claim of improper termination by quoting Title VII of the 1964 Civil Rights Act and stating that "the 'ultimate question' in every Title VII case is whether the plaintiff has proven that the defendant intentionally discriminated against her because of a protected characteristic." "83 The court found, 1) the library's reasons for refusing to hire Schroer were "not its "true reasons, but were . . pretext[s] for discrimination," and 2) library's conduct was sexual stereotyping or discrimination literally "because of . . sex" and violated Title VII. ${ }^{184}$ The Court applied its decision in Price Waterhouse v. Hopkins, ${ }^{185}$ to determine whether sexual stereotyping had occurred in this case. In Price Waterhouse v. Hopkins, a woman named Ann Hopkins won a sexual discrimination claim after she was refused admission as partner based on upon her sex and her actions not being in accordance with sexual stereotypes. ${ }^{186}$ "[D] $]$ iscrimination against a plaintiff who is transsexual - and therefore fails to act and/or identify with his or her gender-is no different from the discrimination directed against Ann Hopkins in Price Waterhouse, who, in sex-stereotypical terms, did not act like a woman."187 "Sex stereotyping based on a person's gender nonconforming behavior is impermissible discrimination, irrespective of the cause of that behavior." "188 The court further pointed out that discrimination based on sexual stereotyping may look similar to discrimination based on Schroer's transsexuality, a condition which has failed to get protection by a majority of federal courts under Title VII. ${ }^{189}$ Nevertheless, the court states it did not matter "whether the library withdrew its offer of employment because it perceived Schroer to be an insufficiently masculine man, an insufficiently feminine woman, or an inherently gender-nonconforming transsexual."190 Further, the Schroer court found that Schroer was "entitled to judgment based on a sex-based disparate treatment theory, in addition to the Price Waterhouse 'sex stereotyping' theory."191 "The court accepted Schroer's argument that 'because gender identity is a component of sex, discrimination on the basis of gender identity is sex discrimination." 192 While a majority of jurisdictions have not followed Schroer's precedent regarding this interpretation of Title VII, it seems to be gaining credibility

182. Id. at $297-98$.

183. Id. at 299 (quoting St. Mary's Honor Ctr. v. Hicks, 509 U.S. 502, 511 (1993)).

184. Id. at 300.

185. Price Waterhouse v. Hopkins, 490 U.S. 228, 251 (1989).

186. Id.

187. Schroer v. Billington, 577 F. Supp. 2d 293, 304 (D.D.C. 2008) (quoting Smith v.

Salem, 378 F.3d 566, 574-75 (6th Cir. 2004)).

188. Id.

189. Id. at 305 .

190. Id.

191. Raflo, supra note 164, at 166 (citing Schroer v. Billington, 577 F. Supp. 2d 293, 305 (D.D.C. 2008)).

192. Id. 
in recent employment discrimination cases involving transgender plaintiffs. $^{193}$

\section{B. State Laws Affecting Transgender Patients and Health Care}

Most legal issues affecting transgender patients in health care involve state laws such as those addressing amendment of birth certificates, ability of a transgender patient to marry, and surrogate health care decision-making on behalf of incapacitated partners. These legal issues are significant to health care because it can directly impact common health care patient interactions such as informed consent, either in a parent-child relationship or a spousal relationship. Furthermore, the ability of a transgender patient to amend his birth certificate could affect the accuracy of medical records or future treatment options provided by the healthcare provider.

\section{Amendment of Birth Certificates}

Fortunately, courts have given more concrete decisions concerning the ability of transgender individuals to amend their birth certificates. The responsibility of maintaining birth and death records remains with state or local jurisdiction. ${ }^{194}$ Surgical evidentiary proof has been required by all states that allow for the amendment of birth certificates. ${ }^{195}$ However, these states do not agree on the level of surgical proof required to amend a birth certificate. $^{196}$ The varying standards give rise to the concern that one transgender individual would be granted an amended birth certificate in one jurisdiction but denied in another. For example, although not in writing, the State of New York and New York City strictly enforce different standards of surgical procedures. ${ }^{197}$ The State of New York requires proof that the applicant has undergone penectomy, or hysterectomy and mastectomy. ${ }^{198}$ New York City requires that the applicant has undergone either vaginoplasty or phalloplasty. ${ }^{199}$ The different standard allow, for example, a transgender individual that has undergone a hysterectomy to be recognized as their identifiable gender in one place but not another. ${ }^{200}$ Unfortunately, the transgender individual has no control over what standards are applied in

193. Nuskey v. Hochberg, 657 F.Supp.2d 47, 58 (D.D.C. 2009); Glenn v. Brumby, 724 F.Supp.2d 1284, 1298 (N.D. Ga. 2010); Glenn v. Brumby, 632 F.Supp.2d 1308, 1315 (N.D. Ga. 2009); Comm'n on Human Rights \& Opportunities v. City of Hartford, No. CV094019485S, 2010 WL 4612700, at *9 (Conn. Super. Ct. Oct. 27, 2010).

194. Dean Spade, Documenting Gender, 59 HASTINGS L.J. 731, 765 (2008).

195. Id. at 768 .

196. Id.

197. Id. at 769 .

198. Id.

199. Id.

200. Id. 
his jurisdiction. ${ }^{201}$ The applicable standard depends on where the transgender individual was born and, more notably, where their birth certificate was issued. ${ }^{202}$

States have denied birth certificates amendments based on the states' interests. In In re Marriage License for Nash, the court claimed that its denial to recognize Nash's amended birth certificate and the subsequent voiding of his marriage were in accord with Ohio's public policy to deny samesex marriage. ${ }^{203}$ Additionally, the court claimed that the approval of the marriage in Nash would "start us down the slippery slope to judicially legislating same-sex marriages, an area within the purview of the legislature alone." 204 The court used the legislature's intent to hold that birth certificates could only be changed in the event of an error or mistake on the original birth certificate. ${ }^{205}$ In 2011, a class action filed against New York City alleged that the "city discriminat[ed] against transgender people by requiring more of them than it does of others who wish to correct birth certificates." ${ }^{206}$ A plaintiff in the suit stated that his female birth certificate has caused "humiliating confusion when he applied for health insurance at a new job."207

In review, it is in the best interest of a health care provider to check with the local laws governing amended birth certificates. If a local statute allows for the modification of birth certificates, the health care provider should focus on the specific requirements to amend, such as surgical requirements. For a summary of states' current policies on modification of gender on birth certificates, refer to Exhibit B.

\section{Amendment of Medical Records}

The evolution of a transgender patient's transition or gender identification is difficult for a health care organization to record in their medical records, whether electronic or physical. The health care organization has to weigh several important considerations, such as what requirements should be put in place to allow for a change in the medical record and what the repercussions of altering the medical record should be. Additionally, the healthcare organization must decide whether it would be altering the sex, gender, or both in the transgender patient's medical record. A health care

201. Id.

202. Id. at $769-70$.

203. In re Marriage License for Nash, No. 2002-T-0149, 2003 WL 23097095, at *5

(Ohio Ct. App. Dec. 31, 2003).

204. Id. at 6.

205. Id.

206. Jennifer Peltz, Transgender People Sue to Have Birth Records Changed, MSNBC.COM (Mar. 22, 2011), http://www.msnbc.msn.com/id/42220931/ns/health-health_ care/t/transgender-people-sue-have-birth-records-changed/.

207. Id. 
organization's policy for altering a transgender patient's medical record could require the patient's sex to be changed only after a patient's undergoes certain medical treatment such as sexual reassignment surgery or until the patient has proof on an amended birth certificate.

If a health care organization allows for only the sex of a transgender patient to be altered in the medical records this may risk raising red flags to the transgender patient's insurance company of the patient's gender transition and possibly denial of any future procedures. Additionally, the swift change of the patient's sex in the medical record and omission of relevant information regarding the patient's transgender or intersex condition may cause a physician or other healthcare professional to improperly diagnose the transgender patient by not considering their past medical history. Furthermore, if a transgender patient is in transition to their identified gender, another health care professional such as a intake coordinator or nurse, may unintentionally offend the transgender patient without knowledge of the transgender patient's transition.

If a health care organization allows for only the gender of a transgender patient to be altered in the medical records to reflect the selfidentified gender of the patient, it may allow for too much subjectivity to the medical records. To compensate for the large number of possible identifications by a transgender patient, the organization can allow for the following categories that have been suggested for transgender friendly patient intake forms: Male, Female, Transgender, Transwoman, Transmale, MTF, FTM, and Transqueer. ${ }^{208}$ While this type of patient identification is more sensitive to transgender patients, it may be aligned with the legal identification of the patient's gender. A healthcare organization needs to keep on file the legal identification of a patient's gender to reconcile any legal documents received or submitted involving the patient. Currently, the Veterans' Health Administration has taken the position of amending birth certificate to reflect the patient's self-identified gender. ${ }^{209}$ To change the patient's name and gender in his/her medical records, the VA asks for transgender patients to submit documentation per the VHA policies. ${ }^{210}$ In Indiana, there is no statutory or case law specifically addressing the requirements for a health care provider to alter the gender or sex in a patient's medical record.

208. Patient Intake, CTR. OF EXCELlENCE For Transgender HEAlth, http://transhealth.ucsf.edu/trans?page=-protocol-intake (last visited Jan. 19, 2012).

209. Veterans Health Administration Transgender Healthcare Directive, NAT'L CTR. FOR TRANSGENDER EQUALITY 4 (June 2011), http://transequality.org/PDFs/VHA_Trans_ Health.pdf.

210. Id. 


\section{Health Care Consent and Advance Directives}

"In general, transgender people should remember that the issuance of a marriage license is not a guarantee that the validity of their marriage will never be challenged in the future."211 As in many states, including Indiana, if an individual is unable or incapable to consent to a health care decision and has not appointed a health care representative, the spouse of the may give consent on behalf of the individual. ${ }^{212}$ However, if a court finds that a transgender individual is the same-sex as his or her partner, making their marriage void, the transgender individual would not be able to consent for their partner unless otherwise directive by advance directive or other instrument. This would give the transgender individual the same options as same-sex couples when trying to give this partner rights to medical decisions. All transgender and LGBT individuals should strongly consider executing an advance directive, which give an individual the ability to name his or her partner as health care proxy, insuring that "his or her partner will not be excluded from health care information and decision-making in the event of routine or emergency medical examinations and procedures."213 Although requirements for advance directives are generally defined by state laws, there is one federal law addressing the advance directives. ${ }^{214}$ In 1990 , Congress passed the Patients Self-Determination Act, requiring that health care providers receiving Medicaid and Medicare to provide information to patients concerning their individual rights to make medical decisions under state law and the right to create an advance directive. ${ }^{215}$

"While some state laws provide for an advance directive that allows one and to express preferences concerning life-sustaining treatment, name an agent to make health care decisions or do both, some states have separate statutes for living wills and durable power of attorney for health care.,"216 Depending on the device executed, same-sex couples, including transgender couples, are given the option to appoint their partner as a surrogate of medical decisions at all times, including when the patient is incapacitated or unable to communicate. ${ }^{217}$ Depending on the jurisdiction, individuals can execute a combination of these legal devices. ${ }^{218}$

Additionally, it is important to note that a conscious clause is available

211. Nothing but the Truth: Busting Common Myths about TransgenderRights, LAMDA LEGAL (Dec. 14, 2007), http://www.lambdalegal.org/publications/nothing-but-the-truth.

212. IND. CODE $§ 16-36-1-5$ (2011).

213. Shawna S. Baker, Where Conscience Meets Desire: Refusal of Health Care Providers to Honor Health Care Proxies for Sexual Minorities, 31 WOMEN's RTS. L. REP. 1 (2009).

214. 102 AM. JUR. 3D Proof of Facts $\S 95$ (2008).

215. Baker, supra note 213, at 2.

216. 102 AM. JUR. 3D Proof of Facts $\S 95$ (2008).

217. Baker, supra note 213, at 20.

218. Id. 
to health care providers to exercise. ${ }^{219}$ Conscious clauses provide healthcare providers with "the right to refuse to participate in certain medical procedures, treatments or services. ${ }^{220}$ A majority of states' conscious clause legislation is narrowly focused on abortion. ${ }^{221}$

\section{RECOMMENDATIONS FOR FUTURE TRANSGENDER LEGAL ISSUES}

The beginning of this article began by articulating the definition of patients' rights and how these rights are not guaranteed for transgender patients. While most organizations do provide for a patient bill of rights that may or may not include transgender patients, this is not legally binding or a way to state a claim for a transgender patient. Additionally, the Consumer Bill of Rights and Responsibilities from the 1998 The President's Advisory Commission on Consumer Protection and Quality in the Health Care included an anti-discrimination that included based on sex or sexual orientation. The remedy listed under the Consumer Bill of Rights and Responsibilities contains only information for the consumer complaint process. Furthermore, the Consumer Bill of Rights and Responsibilities lists public and private health plans procedures for responding to consumer complaints.

Recently, the Patients' Rights listed in the Affordable Care Act does not contain an anti-discrimination clause but relates generally to insurance fraud and coverage despite pre-existing conditions. ${ }^{222}$ To give transgender federal protection from discrimination, the Affordable Care Act would need to be amended to prohibit discrimination based, on: race, ethnicity, national origin, religion, sex, gender identity, age, mental or physical disability, sexual orientation, genetic information, or source of payment. ${ }^{223}$ Until a federal anti-discrimination clause is added to the Affordable Care Act, it is up to health care organization to include and enforce similar ant-discriminatory policies within their organization. This emphasis should be on the enforcement of the policy and penalties for violation of the policy. Furthermore, it is essential that all patients, including transgender patients, feel comfortable filing complaints of discriminatory treatment with the health care organization.

As with any areas of law, the wearisome factor of transgender legal issues comes from the lack of consistency by courts in interpreting the laws, such as Title VII. Furthermore, court opinions lack uniformity involving amendment of birth certificates and transgender right to marry. The majori-

219. Id. at 14.

220. Id.

221. Id. at 15 .

222. Patient's Bill of Rights, HEALTHCARE.Gov, http://www.healthcare.gov/law /features/rights/bill-of-rights/index.html (last visited Jan. 16, 2012).

223. AM. CANCER SOC'Y, supra note 55. 
ty of court decisions involving transgender individuals involve interpreting the terms sex and gender and applying these terms to the appropriate statute. Several courts follow the precedent set by Corbett $v$. Corbett, which improperly interpreted sex and gender to be biologically determined at birth and not subject to modification. Modern courts of today should realize that the Corbett decision was made in 1970, before the development of modern medical technology; courts did not have any reason to understand and research the legal aspects of gender and sex modifications.

Instead of following an outdated decision such as Corbett, modern courts should look to decisions like In re Heilig, in which the court was thorough in its research of medical definitions, treatises, and opinions on gender and sex. From this research, the Heilig court was able to properly define sex and gender in accordance with current medical definitions, which states that gender relates to a person's psychosexual individuality or identity, while sex refers to a person's anatomical or biological sex. ${ }^{224}$ If future courts take the lead of the Heilig court, and align their interpretations of these terms with the common medically accepted definition, the legal community will find the laws more reliable and be able to better represent their transgender clients. Legal professionals will be able to bring cases under Title VII employment discrimination with a concrete definition of gender to be used in gender discrimination claims involving transgender plaintiffs.

Furthermore, if the courts begin to consistently define these terms to be in conjunction with the medical definitions, this allows for non-legal professionals, such as medical professionals, transgender patients, employers, and layman, to better understand the current interpretations of laws related to transgender. For example, with more consistency, a nurse or physician would be more knowledgeable in assisting transgender patients on their legal rights and remedies for discrimination, consent of a partner, claims against insurance denial, etc. Currently, it is a challenge for legal professionals to understand the legal rights and remedies of a transgender patient. It would be an unreasonable task to ask our healthcare professionals interpret the conflicting current court opinions concerning transgender patients and to keep up-to-date with any future court opinions. For this reason, the following recommendations are given to make healthcare providers knowledgeable on how to ensure that its medical environment and its healthcare professionals' actions are sensitive to the needs of transgender patients.

\section{RECOMMENDATIONS FOR HEALTH CARE PROVIDERS}

"All citizens deserve the right to proper medical treatment regardless 
of their gender identity."225

As demonstrated, current federal and state laws have gaps that do not protect transgender patients from discrimination by giving transgender patients a claim of action. A significant gap relevant to federal statutes, such as Title VII, and state statutes, such as birth certificate amendments, and in turn marriage rights, is the interpretation of the terms "sex" and "gender." The discrepancy occurs when courts interpret "sex" and "gender" as synonymous terms that cannot be altered from the sex determined biologically at birth. Alternatively, medicine defines "sex" and "gender" as different terms, in which an individual's sex can be altered. Until the legal and medical interpretations of these terms are aligned, it is up to the health care community and individual health care organizations to protect transgender patients from discriminatory treatment, and honor their rights as a patient.

All healthcare facilities should be adequately prepared to provide competent and compassionate care for transgender patients by becoming familiar with recent research and striving to understand the lived experience of the transgender patient. ${ }^{226}$ Unfortunately, because of uncomfortable encounters, many transgender patients avoid health care facilities, leaving them to look for their medical care needs, such as hormones, on black markets. $^{227}$ Silicone injections are another extremely dangerous procedure undergone by transgender individuals, which are often performed without the assistance of a health care professional. ${ }^{228}$ Silicone injections are used for body modifications such as creating the image of shapely hips or changing other various body parts. ${ }^{229}$ "These tragic events occur because people find other ways to get the care that they need because they feel that they can no longer get care in the mainstream healthcare system."230

A study performed in 2005 by The Transgender Training Project of the New England AIDS Education and Training Center found that providers had: 1) a desire to treat transgender patients respectfully but admitted discomfort and lack of tools for specific interviewing/assessments, 2) experience with transgender patients but lacked information on distinctions among transgender experiences, 3) time constraints that created barriers to developing trusting relationships with their transgender patients, 4) frustrations with the lack of information, research, and guidelines to treat transgender patients, and 5) beliefs that transgender people themselves are an essential teaching resource. ${ }^{231}$ According to the University of Michigan

225. DeCleene, supra note 67 , at 138.

226. Sue Thomas, Competent Care of the Transgendered Patient: Nurse as Advocates, UNIV. OF VT. DEP'T OF NURSING 2 (2004), http://www.transgendered-soul.com/Transition PDF/Competentcareoftg4.pdf.

227. Silverman, supra note 62, at 350 .

228. Id.

229. Id.

230. Id.

231. Lurie, supra note 4, at 93-94. 
Medical School, better care for LGBT patients can be achieved through four simple changes: 1) updating the physical environment of the facility; 2) adding or changing intake and health history form questions; 3 ) improving provider-patient interviews, and 4) increasing the staff's knowledge about and sensitivity to LGBT patients. ${ }^{232}$

\section{A. Adapt your Intake Forms and Intake Process}

Regardless of the training or level of sensitivity of the provider, if the personnel at the front desk unintentionally offend a transgender patient, this can have destructive affects for both the future health of the transgender patient and the reputation of the healthcare provider. ${ }^{233}$ A common example occurs either by the actions of an intake employee towards a transgender patient or when the transgender patient is filling out intake forms during the intake process. Several problems can occur here; for example, transgender individuals may have identification such as a driver's license or birth certificate that represents their legal gender, their legal birth name, and their gender presentation prior to their period of gender transition, thus leading to the wrong gender identification in the clinical record. ${ }^{234}$

The commonly used intake forms can cause a transgender patient to feel discouraged and mistrust the health care system. First, forms typically ask for sex based on the binary schema by providing two boxes, male and female. A transgender patient may not identify with either male or female, or may feel uncomfortable identifying with either gender. Refer to Exhibit $\mathrm{C}$ for an example of a commonly used intake forms that have been revised to be inclusive of transgender patients. The proposed changes to intake forms include offering the following four options for relationship status: single, married, partnered, and other. ${ }^{235}$ Additionally, the waiting room atmosphere can create an unwelcoming or unaccepting atmosphere that may cause a transgender patient to have doubts about the healthcare facility, giving him or her less incentive to be honest with their treating medical staff. Proposed updates to the waiting room include offering at least one unisex restroom, a visible non-discrimination statement, and LGBT specific media including national or local magazines, posters showing racially and ethnically diverse same-sex couples, and brochures about LGBT health concerns. ${ }^{236}$

As discussed earlier, health care organizations have several competing considerations when determining whether to alter medical records of

232. Caring for Lesbian, Gay, Bisexual, and Transgender Patients, A University of Michigan Resource Guide, UNIV. OF MICH. MED. SCH. 10 (2005).

233. Lurie, supra note 4, at 104.

234. Silverman, supra note 62, at 348.

235. UNIV. OF MICH. MED. SCH., supra note 232, at 12.

236. Id. at 11 . 
transgender patients, electronic or physical. To combat these concerns, health care organizations can allow for the gender of a patient to be changed based on the self-identification of that patient. Since statutory guidance is not present for health care organizations on when to alter the sex of a patient on a medical record, it is would be in best practice for a health care organizations to develop its own policies or keep the biologically born sex of the patient also available on the medical record. For example, if a transgender patient was biologically born female and is currently transitioning to a male, but identifies himself as a female to male transgender; it would be reflected in his medical record by having his sex as female and his gender as FTM. This approach allows for the sensitivity of gender identification to transgender patients, while keeping the organization legal in compliance. Additionally, this notification to a physician, nurse, or other health care professional, such as an intake coordinator, that can assist in treatment, diagnosis, and sensitivity during social interactions.

\section{B. A Healthcare Provider's Actions and Words}

Health care providers have the responsibility to present their medical care in the best interest of their patients. If a provider is aware that transgender patients often have misgivings about providers, then the provider is responsible for educating herself on strategies that can help overcome these doubts. Now it is important to note that if a provider lacks the proper training on how to overcome these obstacles with transgender patients, that does not mean the provider is lacking in ability. Regrettably, " $[t]$ ranssexual care is currently seldom taught in medical school, and medical and endocrinology textbooks are often outdated and misinform readers. ${ }^{237}$ Thus, it is up to the provider to seek additional resources and knowledge on how to effectively treat transgender patients. Transgender individuals often cite providers' actions and choice of words as reasons not to trust them.

\section{Use of Proper Pronouns}

The biggest mistake by any health care provider or any service provider is the improper use of pronouns when referring to a transgender individual. The proper reference to a transgender individual is to use the pronoun associated with the identified gender of that particular individual. ${ }^{238}$ Providers should be aware that not all people within the transgender community identify with the term, "transgender," or are aware of its mean-

237. DeCleene, supra note 67, at 138 (citing R. NICK GORTON ET. AL., MEDICAL Therapy \& Health MAINTENANCE For Transgender MEN: A Guide for Health Care Providers 9 (2005), available at http://nickgorton.org).

238. Lurie, supra note 4, at 97. 
ing. ${ }^{239}$ Providers may be surprised by the increased comfort in transgender patients when the providers follow just this one important guideline.

\section{A Provider's Approach Before Conducting an Interview}

While referring to a transgender patient with the proper pronoun is important, it is not the only respect to keep in mind when treating a transgender patient. All providers, like all people, have emotions or thoughts they cannot control. As a health care provider, it is important to not pre-judge a transgender patient. A provider may have pre-conceived notions on what he/she believes transgender people do or do not do in their everyday lives. Nonetheless, it is extremely important for a medical professional to approach a transgender patient without any prejudice concerning the choices and lifestyle of that patient. The provider should approach the transgender patient as an individual, while keeping in mind common health care risks association with the transgender population. For example, many physicians tend to over focus on the sexual history of transgender patients. While this is an important health risk for some transgender people, it is not a health risk for all transgender people. This concept is in agreement with a health care provider's respect for patient's autonomy and self determination.

\section{The Interview Process}

Unintentional discrimination towards a transgender patient by a provider can occur during the interviewing process. As previously discussed, unless the treating physician feels the sexual history of that particular transgender patient is significant, the provider should avoid dwelling on the sexual history of that transgender patient. Transgender patients are often stigmatized as having a promiscuous sexual history. Stereotyping a transgender patient by assuming he or she has a complicated sexual history can be another factor that causes the patient to distrust the health care community. "Understanding that there is a power relationship, but also wanting to build rapport, asking questions in an affirming way and not assuming to know what a patient wants or needs were also seen as essential to effective interviewing.,240

The best way for a provider to avoid stigmatizing a transgender patient is for the provider to conduct the interview by asking open-ended questions. "Providers need to ask open-ended questions that are general in scope" so that "patients can answer as is appropriate to them."241 Providers 
should use the same language as patients in describing themselves but avoid using any derogatory terms the patient may use to describe themselves. ${ }^{242}$

\section{Be Knowledgeable on the Health Needs of Transgender Patients}

Health care professionals have a duty to be better informed about the health needs of the transgender community, just as they have the duty to be informed about any patient. As previously discussed, it is important for a provider to treat a transgender patient as he/she would treat a nontransgender patient, by asking questions about the patient's family history of high blood pressure, cholesterol, cancer, etc. Yet, the provider needs to also keep in mind that equal treatment, or focusing only on the transgender patient's health concern that do not relate to being transgender, can worsen the environment for transgender patients. As a transgender individual, transgender patients have specific need related to being transgender that should not be ignored. Unfortunately, transgender patients have had more discriminatory life experiences than most patients. The discrimination that these individuals face in everyday social settings, such as the workplace, is due to their transgender status, which makes their mental health issues deserving of special attention. ${ }^{243}$ "Although the neutral posture espoused by providers is intended to 'depathologize' LGBT people, it may divert attention from the issues of discrimination, stigmatization, and violence, which affect the mental health of sexual and gender minorities in rural settings."244

Some of the common health risks cited for transgender individuals are increased risk of substance abuse, suicide, depression, and other mental health disorders. Again, as a provider, these health risks should always be considered when treating a transgender patient but should never be the deciding factor in a diagnosis. Providers should be cautious when speaking about these health risks and always remember that for a transgender patient there is a stigmatization attached to many of these health risks. As previously discussed, transgender patients often lack an adequate support team. Providers should keep in mind a transgender patient's current support team when recommending or administering any care.

There are numerous medical concerns for providers to keep in mind when treating transgender patients. Once again, these suggestions are not true for all transgender patients and a provider should base their medical opinion on the individual transgender patient. The research concerning long-term hormone usage is continually evolving and should be referred to frequently by providers. Additionally, a provider should be aware of the interactions of hormones with any other medications used by the

242. UNIV. OF MiCH. MED. SCH., supra note 232, at 12.

243. Cathleen E. Willging et al., Unequal Treatment: Mental Health Care for Sexual and Gender Minority Groups in a Rural State, 57 PsYCHIATRIC SERVs. 867, 870 (2006).

244. Id. 
transgender patients. Transgender patients commonly undergo cosmetic procedures as part of their transition. Many of these cosmetic procedures have side effects and associated risks procedures. Providers should note any past cosmetic procedures undergone by transgender patients when administering care. Furthermore, providers should always give transgender patients all information regarding a procedure prior to getting consent from the transgender patient to perform the procedure. It is important for health care professionals to understand that not all transgender patients feel the need to have sexual reassignment surgery. For some transgender people, taking on their identified gender with the aid of hormones is satisfactory.

\section{Be Knowledgeable about Non-Medical Concerns of Transgender Pa- tients}

To provide a holistic approach to health care, a provider has a duty to understand the personal experiences of his/her patients and the daily struggles they may face. "Whether a hospitalization is related to a sex reassignment surgery or a broken bone, a professional level of knowledge combined with sensitive and empathetic care can help reduce needless stress and facilitate the healing process." 245 Several of the larger problems transgender people are forced to confront have been addressed earlier in this article (e.g., marriage rights, amendment of birth certificates, and recognition of identified gender by the law and society, and employment discrimination). While these problems are worth recognizing, it is important to keep in mind the daily struggles of a transgender person.

From a clinical perspective, a large struggle for some transgender patients is the absence of support by family, friends, and co-workers in transition to their recognized gender. For some, they may have lost members of their support team when they have expressed to the family member or friend that they were transgender. It cannot be doubted that the gender transition process is mentally, physically, and financially exhausting. It is important for a healthcare provider to identify members of a transgender patient's personal support team or the lack of a support team for the patient or possibly assist in creating a support team.

Financial struggles are also a common obstacle for transgender individuals. A serious strain on the financial stability of a transgender individual can involve the loss of income from termination of employment. As previously discussed in the cases involving employment issues, transgender individuals are often wrongfully terminated after starting the transition process or after undergoing a sexual reassignment surgery. While it is possible for a transgender employee to recover under Title VII in some jurisdictions, the costs of legal fees and the loss of income before judgment are often un- 
bearable for most. Additionally, the cost of sexual reassignment surgery can create financial obstacles for many transgender patients. The average cost in 2001 for a male-to-female surgery was about $\$ 10,400$. For a femaleto-male, primary surgery (top surgery) was approximately $\$ 8,500$; and for a female-to-male, bottom surgery was approximately $\$ 9,500 .{ }^{246}$ Because most insurance policies do not cover such procedures, these excessive costs must be paid through out-of-pocket expenses.

\section{E. Attend Trainings/Seminars Dedicated to the Needs of Transgender Pa- tients}

This article is aimed at informing healthcare providers about transgender patients but in no way should this be the end of a provider's education on transgender patients. Instead, this article should provide an overall picture to providers on the current healthcare environment for treating transgender patients. Change must be system wide for a culturally inclusive environment to be created. ${ }^{247}$ "Efforts must be made to reform treatment systems by empowering providers through ongoing training and the enforcement of institutional and public policies prohibiting LGBT discrimination. 248

Furthermore, for a culturally inclusive environment to be created for transgender patients, the patients should not be asked questions to educate the health care providers for educational purposes. "Many transgender people have enough self work to do and enough self stuff going on that the last thing they want to do is train someone on their needs or the needs of the transgender community, so it becomes the provider's responsibility to have that information." 249 Providers should not feel it is the duty of the transgender patient to educate the provider on their needs. ${ }^{250}$ Instead, it is the duty of the healthcare facility to educate its employees on the needs of transgender patients by routinely allowing for training in transgender health needs. ${ }^{251}$

The initiation of a culturally inclusive environment for LGBT patients starts with the revision of current companywide policies and the creation of some new improved policies involving the treatment of diverse patients. In a study conducted by the Transgender Training Project of New England AIDS Education and Training Center, it was found that providers felt there were five specific issues that were institutionally based: 1) agencies have

246. Mary Ann Horton, The Cost of Transgender Health Benefits, TRANSGENDER AT WORK, Sept. 2008, available at $\mathrm{http}: / / \mathrm{www}$. tgender.net/taw/thb/THBCost-OE2008.pdf.

247. Lurie, supra note 4, at 104.

248. Willging et al., supra note 243 , at 870.

249. Lurie, supra note 4, at 99.

250. DeCleene, supra note 67 , at 138 .

251. Id. 
the responsibility to be inclusive and to have policies in place for culturally competent treatment of transgender people; 2) making an agency welcoming should not be up to any one individual; 3 ) individuals who want change within their agencies may not be empowered to create that change; 4) there is a transphobia and resistance among staff; and 5) training and awareness must be across all levels of staff, including front desk staff. ${ }^{252}$ Companywide policies are typically the most time consuming policy changes but can have the largest impact on the reputation of the provider and the treatment of patients.

An easier adjustment for a healthcare facility, which should ideally be implemented with the companywide policies, is to establish an educational training program for all employees to attend that focuses on the needs of transgender patients. The following training suggestions have been identified as training needs for providers: 1) staff at all levels should attend awareness training; 2) transgender people should be trainers; 3 ) appropriate languages to use in interviews should be provided, including role plays of specific interviewing skills; 4) issues may be better incorporated into broader training on diversity or other topics to overcome the potential issue of attendance by providers; 5) utilize training methods that are already in use such as journals, web pages, in-services, or conferences; and 6) incorporate training in curriculum for medical students if the providers is associated with an medical school. ${ }^{253}$ Healthcare providers should utilize the transgender trainers by asking any questions they feel would help them identify or better understand their transgender patients. Transgender trainers can give a face and a voice to the issues transgender people face in everyday society and while at a healthcare facility. The interactions with the trainers, and not the transgender patients, should be the educational resource tool made available to healthcare providers for any concerns or issues they may currently be having with their transgender patients. The training provided by the healthcare facility does not need to be solely focused on the needs of transgender patients. Instead, the available training can be included in other culturally competent training concerning the needs of minority patients.

\section{F. Gain Experience Working with Transgender Patients}

In addition to trainings, all healthcare providers should increase their experience treating transgender patients. "The lack of experience influences a sense of discomfort on the part of the providers, and this can then lead to unhelpful or even hostile treatment of the trans client."254 "This can

252. Lurie, supra note 4 , at 104.

253. Id.

254. Id. at 97. 
be based on lack of knowledge and discomfort."255 Experience working more with transgender patients can relieve any discomfort a healthcare provider may have when treating a transgender patient. Like any skill, experience is needed to become adept at providing care for transgender patients. With additional experience, providers will develop new questions concerning transgender patients that can be addressed with the transgender trainers, creating a continuing educational environment for the providers.

A program designed to educate physicians, nurses, employees, and other healthcare providers through literature, videos and other mediums is not the end of the recommended training that should be made available to health care professionals regarding transgender patients. The mediums provided in these trainings inform providers about the physical, psychological, emotional, and legal struggles of transgender patients. However, being educated on these struggles enables providers to take the next step in giving comprehensive care to transgender patients, which is the ability to begin giving effective treatment for transgender patients in real-life situations. This next step is stated as only "starting" to treat transgender patients because like any new situation, it will take time for the health professional to develop the required skills for appropriately treating transgender patient.

\section{CONCLUSION}

The needs of transgender patients are unmet in the healthcare environment. The medical struggles faced by transgender individuals are virtually ignored by the healthcare community, and typically only discussed when speaking about hormone therapy and sexual reassignment surgeries. The life of a transgender patient is not like the life of other patients. Transgender patients face daily discrimination and alienation from society and even friends and family. By understanding the many legal, medical, emotional, and societal struggles that transgender patients face, a healthcare provider can empathize and better diagnose these patients. A healthcare provider has the duty to be educated on these possible struggles by attending training that gives guidance on providing culturally comprehensive treatment to transgender patients. Furthermore, it is the responsibility of a healthcare facility to better educate its support staff and health care professionals by offering training programs with transgender instructors. The available training could be easily implemented into other culturally competent trainings that are offered regularly and can yield large results in terms of welcoming transgender patients. It is the responsibility of the healthcare community to bridge the gaps left by the law and protect transgender patients from discrimination. To accomplish this, health care professionals need to be knowledgeable about transgender patients and their needs. Fur- 
thermore, transgender patients require rights under most patient bill or rights. It is up to the health care community to be accountable and honor these transgender patients and their rights. 
Exhibit A: 9 recommended principles for correctional health professionals to follow in providing for the needs of transgender prisoners

The management of medical (e.g., medically necessary hormone treatment) and surgical (e.g., genital reconstruction) transgender issues should follow accepted standards ${ }^{1}$ developed by professionals with expertise in transgender health. Determination of treatment necessary for transgender patients should be on a case-by-case basis. Ideally, correctional health staff should be trained in transgender health care issues. Alternatively, they should have access to other professionals with expertise in transgender health care to help determine appropriate management and provide training in transgender issues.

Because inmate-patients may be under different stages of care prior to incarceration, there should be no blanket administrative or other policies that restrict specific medical treatments for transgender people. Policies that make treatments available only to those who received them prior to incarceration or that limit GID treatment to psychotherapy should be avoided. Policies that attempt to "freeze" gender transition at the stage reached prior to incarceration are inappropriate and out of step with medical standards, and should be avoided.

Diagnosed transgender patients who received hormone therapy prior to incarceration should have that therapy continued without interruption pending evaluation by a specialist, absent urgent medical reasons to the contrary. Transgender inmates who have not received hormone therapy prior to incarceration should be evaluated by a health care provider qualified in the area of transgender health to determine their treatment needs. When determined to be medically necessary for a particular inmate, hormone therapy should be initiated and sex reassignment surgery considered on a caseby-case basis. Regular laboratory monitoring should be conducted according to community medical standards.

Treatment for genital self-harm or for complications arising from prior surgery or from self-treatment should be provided when medically necessary.

Correctional health care providers should provide patient education materials to help transgender patients cope with their diagnosis and treatment.

Psychotherapy such as "reparative" therapy or attempts to alter gender identity should not be employed. Reparative therapy inappropriately portrays GID as a mental illness and not a medical condition. 
In matters of housing, recreation, and work assignments, custody staff should be aware that transgender people are common targets for violence. Accordingly, appropriate safety measures should be taken regardless of whether the person is placed in male or female housing areas.

Transgender inmates receiving hormone therapy should receive a sufficient supply upon release to last until a community provider assumes care. Referrals should be made to community-based organizations with sensitive and inclusive services for transgender people.

Correctional policies for management of transgender inmates should be developed and implemented in partnership with local transgender communities, particularly current and former inmates, and transgender service providers when possible.

Exhibit B: List of State Statutes Regarding Amending Birth Certificates.

\begin{tabular}{|l|l|l|l|}
\hline State & $\begin{array}{l}\text { Amend Birth } \\
\text { Certificates }\end{array}$ & $\begin{array}{l}\text { Court } \\
\text { Order }\end{array}$ & $\begin{array}{l}\text { Proof } \\
\text { Required }\end{array}$ \\
\hline Statute \\
\hline
\end{tabular}




\begin{tabular}{|c|c|c|c|c|}
\hline Illinois & & Required & $\begin{array}{l}\text { Doctor's } \\
\text { Note }\end{array}$ & \\
\hline Whatros: & Tes & Requitur & $\sqrt{1010}$ & \\
\hline Iowa & Yes & & $\begin{array}{l}\text { Doctor's } \\
\text { Note }\end{array}$ & \\
\hline 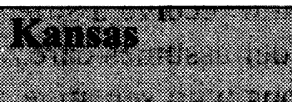 & Tes & & $\begin{array}{l}\text { Doctor's } \\
\text { Note }\end{array}$ & \\
\hline Kentucky & Yes & & $\begin{array}{l}\text { Doctor's } \\
\text { Note }\end{array}$ & \\
\hline Lomitions: & Yes: & Deguired & 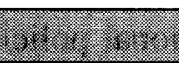 & 28 \\
\hline Maine & Yes & Required & & \\
\hline Matyland:- & Yes: & Reguried & 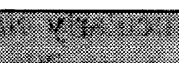 & \\
\hline Massachusetts & Yes & & $\begin{array}{l}\text { Doctor's } \\
\text { Note }\end{array}$ & \\
\hline Mrohong & Yes: & 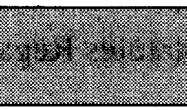 & $\begin{array}{l}\text { Poctor's } \\
\text { Note }\end{array}$ & $\sqrt{12} \sqrt{10}$ \\
\hline Minnesota & Yes & Required & & \\
\hline Mississippi & Yes & 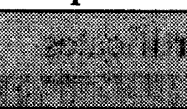 & $\begin{array}{l}\text { Doctor's } \\
\text { Nater }\end{array}$ & \\
\hline Missouri & Yes & Required & & \\
\hline 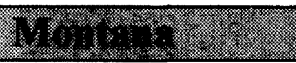 & Yos & Reriving & 50 & 8 \\
\hline Nebraska & Yes & & $\begin{array}{l}\text { Doctor's } \\
\text { Note }\end{array}$ & \\
\hline Tevada & 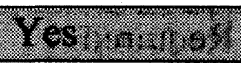 & Required & 20 & 20 \\
\hline New Hampshire & Yes & Required & & \\
\hline 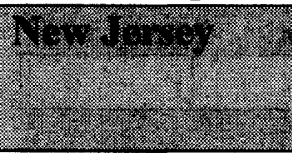 & $x^{2}-2$ and & Reguiled & Note & 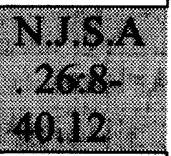 \\
\hline New Mexico & & Required & $\begin{array}{l}\text { Doctor's } \\
\text { Note }\end{array}$ & \\
\hline New York & & Required & $\begin{array}{l}\text { Doctor's } \\
\text { Note- }\end{array}$ & \\
\hline North Carolina & & Required & $\begin{array}{l}\text { Doctor's } \\
\text { Note }\end{array}$ & $\begin{array}{l}\text { N.C.G. } \\
\text { S.A. } \S \\
130 A- \\
118(b)( \\
4)\end{array}$ \\
\hline Nortingakota" & & Reguiricat & $\begin{array}{l}\text { Doctor's } \\
\text { Note }\end{array}$ & \\
\hline Ohio & No & & & \\
\hline
\end{tabular}




\begin{tabular}{|c|c|c|c|c|}
\hline Oklahoma & Yes & Required & \multicolumn{2}{|c|}{$\begin{array}{l}\text { Doctor's } \\
\text { Nate }\end{array}$} \\
\hline Oregon & Yes & Required & & - \\
\hline Penusylvania & Yes: & Requince & $\begin{array}{l}\text { Doctor's } \\
\text { Note }\end{array}$ & \\
\hline Rhode Island & Yes & & $\begin{array}{l}\text { Doctor's } \\
\text { Note }\end{array}$ & \\
\hline South Carolina & Yes & & $\begin{array}{l}\text { Doetor's } \\
\text { Note }\end{array}$ & (1). \\
\hline South Dakota & Yes & Required & & \\
\hline Tennessee & $\mathrm{No}$ & 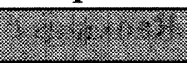 & 8. & $9 \sqrt{2828}$ \\
\hline Texas & Yes & Required & & \\
\hline Utah & Yes & Requines & 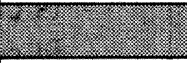 & \\
\hline Vermont & Yes & Required & & \\
\hline Vlrinin & Yes: & Reguired & & \\
\hline Washington & Yes & Required & $\begin{array}{l}\text { Doctor's } \\
\text { Note }\end{array}$ & \\
\hline West Virginia & Yes. & Refuired: & $\begin{array}{l}\text { Doctor's } \\
\text { Note }\end{array}$ & \\
\hline Wisconsin & Yes & Required & & $\begin{array}{l}\text { W.S.A. } \\
69.15(4 \\
\text { (b) }\end{array}$ \\
\hline Wyoming & Yes & Reguires & eic & \\
\hline
\end{tabular}

Exhibit C: Example of Intake Questionnaire

1. What is your current gender identity? (Check and/or circle ALL that apply) ${ }^{256}$

$\square$ Male

$\square$ Female

$\square$ Transgender Female/Transwoman/MTF

$\square$ Genderqueer

$\square \quad$ Additional category (please specify):

$\square$ Decline to answer

2. What sex were you assigned at birth? (Check one) ${ }^{257}$

$\square$ Male

256. CTR. OF EXCELLENCE FOR TRANSGENDER HEALTH, supra note 208.

257. Id. 
Female

Decline to answer ply) ${ }^{258}$

3. What is your current relationship status? (Check all that ap-

$\square$ Single

Married

Partnered

Other

What pronouns do you prefer?

259

Exhibit D: LGBT Youth Rankings of Healthcare Provider Qualities

\begin{tabular}{|c|c|}
\hline Rank 1: & $\begin{array}{l}\text { - Is competent (i.e. has good medical skills) } \\
\text { - Is respectful to me } \\
\text { - Is honest with me } \\
\text { - Listens to me } \\
\text { - Treats gay, lesbian, bisexual and transgender } \\
\text { youth the same as other youth } \\
\text { - Makes me feel comfortable } \\
\text { - Is nonjudgmental }\end{array}$ \\
\hline Rank 2: & $\begin{array}{l}\text { - Is willing to refer me to another provider if they } \\
\text { are not able to take care of all my health needs } \\
\text { - Is educated about HIV transmission and preven- } \\
\text { tion } \\
\text { - Is supportive of my total well being } \\
\text { - Is friendly and personable } \\
\text { - Helps me to make decisions about my health care } \\
\text { - Explains everything to me in "plain language" } \\
\text { - Knows when to consult with colleagues to get } \\
\text { other information/opinions }\end{array}$ \\
\hline Rank 3: & $\begin{array}{l}\text { - Is educated about gay and lesbian health issues } \\
\text { - Is experienced working with youth } \\
\text { - Is intellectually inquisitive } \\
\text { - Does not rush during the visit }\end{array}$ \\
\hline Rank 4: & $\begin{array}{l}\text { - Has a good sense of humor } \\
\text { - Has been working in the health field for a long } \\
\text { time } \\
\text { - Is experienced working gay, lesbian, bisexual }\end{array}$ \\
\hline
\end{tabular}

258. UNIV. OF MiCH. MED. SCH., supra note 232, at 12.

259. CTR. OF EXCELLENCE FOR TRANSGENDER HEALTH, supra note 208. 


\begin{tabular}{|c|c|}
\hline & $\begin{array}{l}\text { youth } \\
\text { - Asks me about my ideas for what is wrong with } \\
\text { my health }\end{array}$ \\
\hline Rank 5: & $\begin{array}{l}\text { - Uses gay-inclusive language during the interview } \\
\text { and on forms I am asked to fill out at the visit }\end{array}$ \\
\hline Rank 6: & - Is educated about transgender health issues \\
\hline Rank 7: & $\begin{array}{l}\text { - Is the same gender as me } \\
\text { - Is experienced working with transgender youth }\end{array}$ \\
\hline Rank 8: & - Has the same sexual orientation as I $\mathrm{do}^{260}$ \\
\hline
\end{tabular}

Exhibit E: LGBT Youth Rankings of Office or Health Center Qualities

\begin{tabular}{|c|c|}
\hline Rank 1: & $\begin{array}{l}\text { - Is clean } \\
\text { - Accepts my health insurance }\end{array}$ \\
\hline Rank 2: & $\begin{array}{l}\text { - Has friendly staff } \\
\text { - Offers screening and treatment for sexually } \\
\text { transmitted diseases } \\
\text { - Allows me to come without my parent/guardian } \\
\text { - Offers HIV testing } \\
\text { - Provides confidential care for minors }(<18 \text { years } \\
\text { old) }\end{array}$ \\
\hline Rank 3: & $\begin{array}{l}\text { - Has information about referrals to mental health } \\
\text { providers experienced with LGBT youth } \\
\text { - Has information about referrals to community } \\
\text { agencies for LGBT youth } \\
\text { - Allows the same provider to see me visit to visit } \\
\text { - Makes sure the provider sees me on-time } \\
\text { - Has an easy process for getting appointments } \\
\text { - Has a short waiting time to get appointments } \\
\text { - Offers mental health services }\end{array}$ \\
\hline
\end{tabular}

260. Neal D. Hoffman, M.D., Katherine Freeman, Dr.PH,. \& Stephanie Swann, Ph.D., Healthcare Preferences of Lesbian, Gay, Bisexual, Transgender and Questioning Youth, 45 J. AdOLESCENT HEALTH 222-229 (2009). 


\begin{tabular}{|c|c|}
\hline Rank 4: & $\begin{array}{l}\text { - Offers support groups for youth } \\
\text { - Offer gynecological care } \\
\text { - Has evening hours available } \\
\text { - Is located near to where I live } \\
\text { - Has weekend hours available } \\
\text { - Asks for input from youth about pro- } \\
\text { grams/services } \\
\text { - Has sliding fee scale for youth without insurance }\end{array}$ \\
\hline Rank 5: & $\begin{array}{l}\text { Displays magazine, health education post- } \\
\text { ers/brochures/videos for youth } \\
\text { - Displays magazine, health education post- } \\
\text { ers/brochures/videos for LGBT youth }\end{array}$ \\
\hline Rank 6: & $\begin{array}{l}\text { - Has an e-mail address for correspondence } \\
\text { - Advertises itself as "transgender friendly" }\end{array}$ \\
\hline Rank 7: & $\begin{array}{l}\text { - Plays good music in the waiting area } \\
\text { - Has a waiting area for youth }\end{array}$ \\
\hline Rank 8: & - Provides care to youth only ${ }^{261}$ \\
\hline
\end{tabular}

Exhibit F: LGBT Youth Rankings of Health Concerns or Problems to Discuss with a Health Care Provider

\begin{tabular}{|l|l|}
\hline Rank 1: & - Depression \\
& - Medication side effects \\
& - STDs \\
& - HIV/AIDS \\
& - Preventative health care (staying healthy) \\
& - STD treatment and transmission issues for part- \\
& ners \\
& - Suicidal feelings \\
& - Taking multiple medications (e.g. chronic illness- \\
& es) \\
& - Nutrition \\
& - Safe sex \\
& - Family problems \\
& - Risky or unsafe sexual behavior \\
\hline
\end{tabular}




\begin{tabular}{|c|c|}
\hline Rank 2: & $\begin{array}{l}\text { - Holistic and complementary treatments } \\
\text { - Harassment or violence in the community } \\
\text { - Harassment or violence at school or work } \\
\text { - Drug use } \\
\text { - Alcohol abuse } \\
\text { - All sexual behavior } \\
\text { - Partner/domestic violence } \\
\text { - Other gynecologic problems } \\
\text { - Sexual relationships } \\
\text { - Menstrual problems } \\
\text { - Future goals in personal life } \\
\text { - Job safety (work-related injuries) } \\
\text { - Smoking } \\
\text { - Sexual orientation } \\
\text { - Having children/parenting options } \\
\text { - Other male sexual health concerns } \\
\text { - Testicular problems } \\
\text { - Pregnancy prevention } \\
\text { - Body piercing } \\
\text { - Talking to parents/family about being LGBT } \\
\text { - Tattooing }\end{array}$ \\
\hline Rank 3: & $\begin{array}{l}\text { - Sexual pleasure } \\
\text { - Taking feminizing or masculinizing hormones } \\
\text { - Being transgender } \\
\text { - Masturbation } \\
\text { - Talking to parents/family about being } \\
\text { transgender }\end{array}$ \\
\hline
\end{tabular}


